\title{
Androgenic control of the cyclic AMP-dependent protein kinase isoenzymes of the rat epididymis
}

\author{
S. Mongkolsirikieat and M. Chulavatnatol \\ Department of Biochemistry, Faculty of Science, Mahidol University, Rama VI Road, \\ Bangkok 10400, Thailand
}

\begin{abstract}
Summary. The specific activity of the type I and type II isoenzyme forms of the cAMP-dependent protein kinase (EC 2.7.1.37) in the caput epididymidis of the intact rat was less than that of the caudal region while the isoenzyme ratio (type II :type I) of the former was greater than that of the latter, with type II being the predominant form in both regions. By 7 days after castration, the specific activities in both regions had decreased to the same level. The isoenzyme ratio of the caudal region increased to that of the caput region which remained unchanged after castration. The change in the isoenzyme ratio in the caudal region was mainly due to loss of the type $I$ isoenzyme. The castration effects were reversed by testosterone administration.
\end{abstract}

\section{Introduction}

The importance of the epididymis in sperm maturation and hence male fertility has attracted much attention for a long time (for review, see Mann \& Lutwak-Mann, 1981). Androgens appear to control epididymal functions by regulating several biochemical and physiological processes (for review, see Brooks, 1981). However, limited studies have been reported on protein phosphorylation in the epididymis even though this important regulatory mechanism, catalysed by protein kinases, has been extensively investigated in other tissues (Greengard, 1978; Carlson, Bechtel \& Graves, 1979; Glass \& Krebs, 1980; Walter \& Greengard, 1981; Cohen, 1982; Sharma, 1982). Epididymal protein phosphorylation has been shown to depend on testosterone (Kadohama \& Turkington, 1974). There appear to be 3 forms of protein kinase in rat epididymal tissue extracts: cyclic AMPdependent, cyclic AMP-independent and cyclic GMP-dependent. Activities of the cyclic AMPdependent and -independent protein kinases of the caput epididymidis from immature rats are elevated after testosterone administration (Bernard \& Wassermann, 1972) and the ratio of the cyclic AMP-dependent to the cyclic GMP-dependent protein kinases increases during post-natal development (Kuo \& Williams, 1979). As in other tissues, the cyclic AMP-dependent protein kinase of the rat epididymis also exists as two isoenzymes, types I and II (Biswas \& Majumder, 1982). The isoenzymes differ in charge and can be separated by ion-exchange chromatography. We have now examined the effect of androgen on the two isoenzymes of the cyclic AMP-dependent protein kinase from the caput and the cauda regions of the rat epididymis.

\section{Materials and Methods}

Adult albino Fischer rats weighing 250-300 g were divided into four groups: intact control, castrated, castrated with testosterone treatment and castrated with oil (vehicle) treatment. Castration was performed by the scrotal route under pentobarbitone sodium anaesthesia ( $5 \mathrm{mg}$ 
Nembutal $/ 100 \mathrm{~g}$ body weight). Testosterone was administered by daily subcutaneous injection of testosterone propionate (Schering A.G., Berlin/Bergkamen, West Germany) dissolved in safflower oil (Hain Pure Food Co., Los Angeles, U.S.A.) at a dose of $1 \mathrm{mg} / \mathrm{kg}$ body weight. During the experiment, all rats were maintained on normal diet and water under a daily cycle of 13-h light and 11-h darkness.

Seven days after castration, each epididymis was surgically removed from rats under ether anaesthesia. The epididymis was dissected free from fat and divided into the caput and cauda region. They were washed twice in Hank's balanced salt solution (HBSS), containing $0 \cdot 138 \mathrm{M}$ $\mathrm{NaCl}, 4 \cdot 17 \mathrm{~mm}-\mathrm{NaHCO}_{3}, 0.3 \mathrm{~mm}-\mathrm{Na}_{2} \mathrm{HPO}_{4}, 5.4 \mathrm{mM}-\mathrm{KCl}, 0.4 \mathrm{~mm}-\mathrm{KH}_{2} \mathrm{PO}_{4}, 1.26 \mathrm{~mm}-\mathrm{CaCl}_{2}, 0.49$

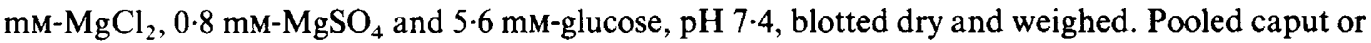
cauda epididymal segments were chopped into small pieces in the medium using a pair of scissors. The spermatozoa were released by gentle passage into and out of a Pasteur pipette. The tissue pieces were allowed to settle and the supernatant fluid was discarded. The tissue pieces were then resuspended in HBSS and centrifuged through a layer of $3 \%$ Ficoll in $0.9 \%(\mathrm{w} / \mathrm{v}) \mathrm{NaCl}$ at $35 \mathrm{~g}$ for 5 min. The final pellet was resuspended in HBSS. The above procedure was carried out at $4^{\circ} \mathrm{C}$. The contamination by spermatozoa in the washed tissue was determined using a haemocytometer and was $<5 \%$ of the total spermatozoa in the initial fluid. Parts of the washed tissue were fixed in Bouin's fluid, embedded in paraffin wax and stained with haematoxylin-eosin; phase-contrast microscopy showed the normal appearance of the cuboidal epithelial cells.

The rest of the washed tissue was homogenized in 1-2 volumes of $0.25 \mathrm{M}$-sucrose in $50 \mathrm{mM}$-Tris-

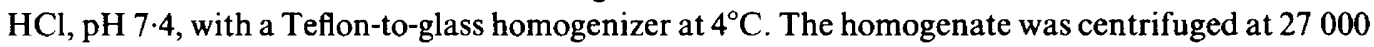
$g$ for $15 \mathrm{~min}$ at $4^{\circ} \mathrm{C}$. Only the supernatant fluid was used as the source of the enzyme.

Protein kinase activity was assayed at $37^{\circ} \mathrm{C}$ according to the method of Reddi, Ewing \& Williams-Ashman (1971). The assay mixture $(125 \mu \mathrm{l})$ contained $375 \mu \mathrm{g}$ salmon protamine (Sigma, St Louis, Missouri, U.S.A.), $10 \mathrm{~mm}-\mathrm{MgCl}_{2}, 1 \mathrm{~mm}$-EDTA, $10 \mathrm{~mm}-\mathrm{NaF}, 10 \mathrm{~mm}-\beta$-mercaptoethanol, 2 mM-theophylline, $1 \mathrm{~mm}-\left[\gamma^{32} \mathrm{P}\right] \mathrm{ATP}\left(5 \times 10^{4} \mathrm{c} . \mathrm{p} . \mathrm{m}\right.$. $\left./ \mathrm{nmol}\right), 10 \mu \mathrm{M}$-cAMP, $10 \mathrm{~mm}$-Tris-HCl, pH 6.5 , and an appropriate amount of epididymal homogenate. Homogenate preheated at $80^{\circ} \mathrm{C}$ for 10 min was used as the assay control. In these conditions, the product formation was linear with incubation time up to $10 \mathrm{~min}$.

$\left[\gamma^{-32} \mathrm{P}\right] \mathrm{ATP}$ was prepared from ${ }^{32} \mathrm{Pi}$ (sp. act. $10 \mathrm{mCi} / \mathrm{ml}$; Radiochemical Centre, Amersham, U.K.) as described by Glynn \& Chappell (1964).

Before loading onto a DEAE-cellulose column $(1.2 \times 7 \mathrm{~cm})$, the homogenate was dialysed against 50 volumes of $10 \mathrm{~mm}$-potassium phosphate buffer, $\mathrm{pH} 7 \cdot 0$, for $3 \mathrm{~h}$ at $4^{\circ} \mathrm{C}$. The column was equilibrated with the phosphate buffer and eluted with a linear gradient of 10 to $500 \mathrm{~mm}$-potassium phosphate buffer, $\mathrm{pH} 7 \cdot 0$. In all cases, the column recovery was $95-130 \%$ of the applied protein kinase activity.

\section{Results}

\section{Protein kinase activity of the epididymal tubules}

It was established that the homogenization yielded about $80 \%$ of the total protein kinase activity in the soluble fraction and the remainder was associated with the pellet fraction. The specific activity of the soluble protein kinases of the cauda epididymal tubule was significantly $(P$ $<0.001$ ) greater than that of the caput epididymidis (Table 1). However, androgen-deprivation by castration for 7 days depressed the enzyme activity in both parts of the tubules to approximately the same level, and about one-third and one-half of the enzyme activity was lost from the caput and the cauda tubules respectively. Administration of testosterone restored the activity to $75-80 \%$ of the intact control values. Administration of the vehicle, safflower oil, had no restorative effect. The epididymal weight decreased by half in 7 days after castration but was maintained by the administration of testosterone. 
Table 1. Effect of castration and testosterone treatment on protein kinase activity in the rat epididymis

\begin{tabular}{lcc}
\hline & \multicolumn{2}{c}{$\begin{array}{c}\text { Protein kinase activity } \\
\text { Treatment }\end{array}$} \\
\cline { 2 - 3 } \multicolumn{1}{c}{ (pmol ${ }^{32} \mathbf{P}$ incorporated/min/mg protein) } \\
\cline { 2 - 3 } Caput epididymidis & Cauda epididymidis \\
\hline Intact (control) & $135 \pm 9(11)$ & $205 \pm 31(11)$ \\
Castrated (7 days) & $89 \pm 20(14)$ & $101 \pm 24(14)$ \\
Castrated (7 days) + oil & $74 \pm 15(5)$ & $107 \pm 18(6)$ \\
Castrated (7 days) + testosterone & $107 \pm 19(7)$ & $152 \pm 22(6)$ \\
\hline
\end{tabular}

Values are mean \pm s.d. for the no. of rats given in parentheses.

\section{Protein kinase isoenzymes}

Although a small column $(1.2 \times 7 \mathrm{~cm})$ of DEAE-cellulose was used, it was still necessary to pool soluble fractions from 3 (intact) or 7 (castrated) rats. To facilitate comparison between the enzyme profiles from intact control and castrated rats, approximately equal activities of the material from both groups were separately applied to the same column.

Protein kinase activity of the caput or cauda epididymidis was clearly resolved into two isoenzymes, type I being eluted from the column at 50-75 mM-potassium phosphate and type II being eluted at $180-210 \mathrm{~mm}$ (Text-fig. 1). The resolution capacity of the column was prechecked

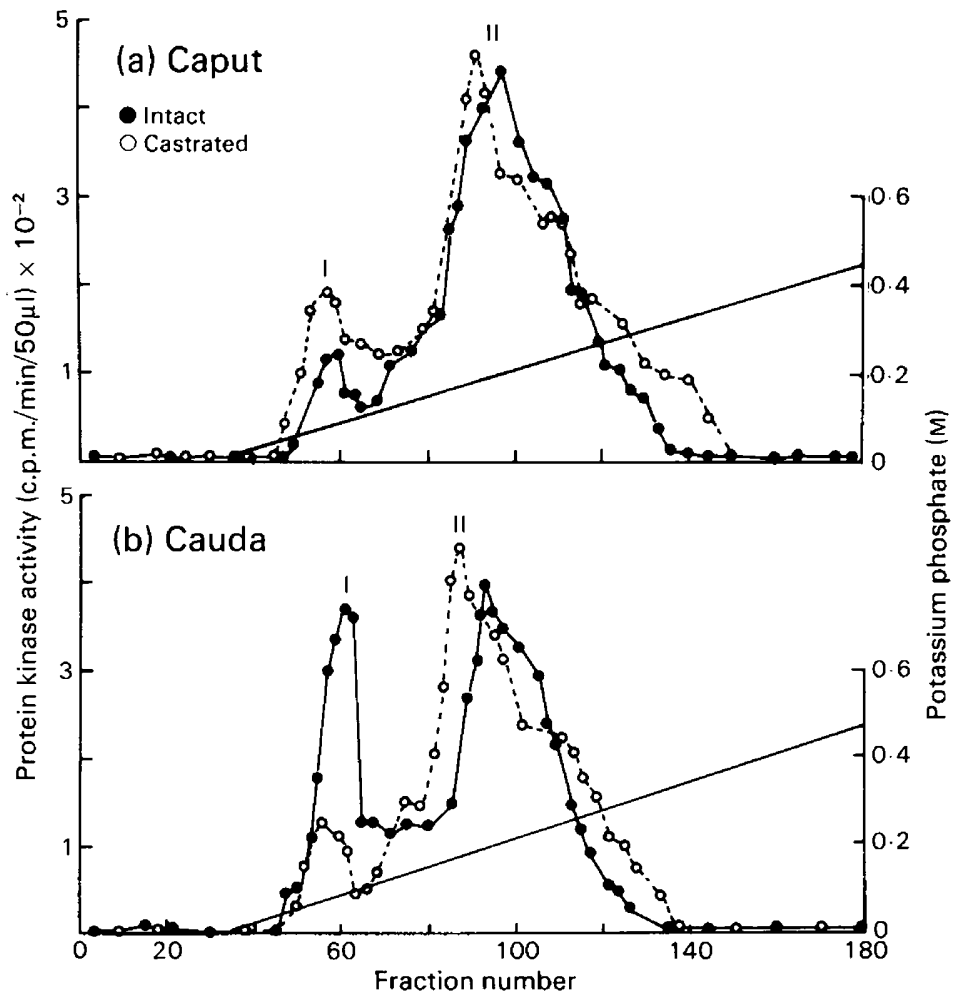

Text-fig. 1. Activity profiles of protein kinases from the (a) caput and (b) cauda epididymidis of intact and castrated rats. Isoenzyme types I and II were resolved in a DEAE-cellulose column $(1.2 \times 7 \mathrm{~cm})$, eluted with a phosphate buffer gradient. The total activities applied to the column were (a) 7.2 and 9.8 and (b) 15.6 and $12.4 \mathrm{nmol}^{32} \mathrm{P}$ incorporated/min from the epididymis of intact and castrated rats respectively. The phosphate gradient is represented by the straight line without symbols. 
with testicular protein kinase prepared according to Lee, Radloff, Schweppe \& Jungman (1976); protein kinase I of this preparation was eluted at $80 \mathrm{~mm}$-potassium phosphate and type II at $210 \mathrm{~mm}$ (data not shown). The salt concentrations agreed with the reported values (Lee et al., 1976).

Protein kinase II was the predominant form in the epididymal tubules; protein kinase I was a minor fraction in the caput region but its concentration was greater in the caudal part. If the activity profile was divided at the trough between two peaks, the approximate ratio between type II and type I isoenzymes can be estimated. From three preparations, the isoenzyme ratios (type II :type I) were $3.4 \pm 1.0$ and $2.5 \pm 0.5$ for the caput and the cauda epididymidis respectively. By 7 days after castration, the caput epididymidis showed no change in the activity profile (Text-fig. 1a) or in the isoenzyme ratio $(3.9 \pm 0.4, n=3)$. In the cauda epididymidis the type I isoenzyme was much more depressed than type II (Text-fig. 1b) and the ratio increased significantly $(P<0.001)$ to $4 \cdot 1 \pm 0.8(n=3)$. In fact, the activity profile of each region of the epididymis from the castrated rats appeared similar to that of the normal caput epididymidis (Text-fig. 1). The isoenzymes from the castrated rats were eluted at salt concentrations slightly lower than those of the normal rats, but this was not consistently seen among the 3 preparations.

In a preliminary study, $10 \mu \mathrm{M}$-cAMP stimulated type I isoenzyme of the normal caput epididymidis to $80 \%$ but did not affect that of the caudal region. Under the same conditions, type II isoenzyme from either region of the normal epididymis was stimulated up to $30 \%$.

\section{Discussion}

Since protein kinases are also present in the epididymal fluid and spermatozoa (Garbers, First \& Lardy, 1973; Hoskins, Stephens \& Hall, 1974; Lee \& Iverson, 1976; De-eknamkul, 1980; Majumder, 1981), it is essential to wash the chopped tubules before release of the tubular protein kinases by homogenization. For this reason, the results of the present study should not have been affected by contamination by epididymal fluid and spermatozoa, and should therefore be more accurate than those using unwashed tubules (Bernard \& Wassermann, 1972; Kuo \& Williams, 1979).

Our finding of a difference in the specific activity of protein kinase (Table 1) between the caput and the cauda epididymidis clearly extends the list of enzymes with differential activities along the epididymis (Brooks, 1981). However, protein kinase is the first enzyme so far studied that shows regional difference in the isoenzyme composition (Text-fig. 1). The importance of these regional differences is still unknown but they could be related to the differential phosphorylation of acidic chromatin proteins observed in the two parts of the epididymis (Kadohama \& Turkington, 1974).

Like several other epididymal enzymes, the protein kinase activity is androgen-dependent since its activity decreases after castration but is maintained by testosterone administration (Table 1). Although both isoenzymes of the caput region are equally sensitive to androgen withdrawal (Textfig. 1a), the high sensitivity to androgen withdrawal of the protein kinase I of the cauda epididymidis (Text-fig. 1b) is similar to that observed in two other steroid-sensitive tissues, the ventral prostate and levator ani muscle (Fuller, Byus \& Russell, 1978). The importance of specific regulation of the type $\mathrm{I}$ isoenzyme in the cauda epididymidis by testosterone must await further study on its cellular location and its phosphorylation products. Nevertheless, the column recovery is high and its variations cannot be correlated with the observed loss of the type I isoenzyme.

With protamine as substrate, cAMP does not stimulate the unfractionated protein kinases from rat epididymis (Bernard \& Wassermann, 1972). So the presence of a cAMP-dependent form cannot be determined by the data in Table 1 . However, a study by Biswas \& Majumder (1982) and our preliminary observations on the fractionated enzymes suggest that each isoenzyme in Text-fig. 1 is a mixture of both cAMP-dependent and -independent forms. Further work will be needed to establish the relationship between these two forms.

S.M. received a scholarship from the Faculty of Graduate studies, Mahidol University. We thank Thitika Vajrodaya for drawing the figures and Urai Sajjaharutai for typing the manuscript. 


\section{References}

Bernard, E.A. \& Wassermann, G.F. (1972) Protein kinase activities in rat epididymis. Effect of maturation and testosterone treatment. Biochem. Biophys. Res. Commun. 49, 434-440.

Biswas, R. \& Majumder, G.C. (1982) Purification and properties of cyclic AMP-dependent protein kinase from rat epididymis. J. Reprod. Fert. 65, 29-37.

Brooks, D.E. (1981) Metabolic activity in the epididymis and its regulation by androgens. Physiol. Rev. 61, 515-555.

Carlson, G.M., Bechtel, R.J. \& Graves, D.J. (1979) Chemical and regulating properties of phosphorylase kinase and cyclic AMP-dependent protein kinase. Adv. Enzymol. 50, 41-115.

Cohen, P. (1982) The role of protein phosphorylation in neural and hormonal control of cellular activity. Nature, Lond. 296, 613-620.

De-eknamkul, W. (1980) Studies of sperm surface and epididymal fluid protein kinase. M.Sc. thesis, Mahidol University, Bangkok.

Fuller, D.J.M., Byus, C.V. \& Russell, D.H. (1978) Specific regulation by steroid hormones of the amount of type I cyclic AMP-dependent protein kinase holoenzyme. Proc. natn. Acad. Sci. U.S.A. 75, 223-227.

Garbers, D.L., First, N.L. \& Lardy, H.A. (1973) Properties of adenosine $3^{\prime}, 5^{\prime}$-monophosphate-dependent protein kinase isolated from bovine epididymal spermatozoa. J. biol. Chem. 248, 875-879.

Glass, D.B. \& Krebs, E.G. (1980) Protein phosphorylation catalyzed by cyclic AMP-dependent and cyclic GMP-dependent protein kinases. Ann. Rev. Pharmac. Toxicol. 20, 363-388.

Glynn, I.M. \& Chappell, J.B. (1964) A simple method for the preparation of ${ }^{32} \mathrm{P}$-labelled adenosine triphosphate of high specific activity. Biochem. J. 90, 147149.
Greengard, P. (1978) Phosphorylated proteins as physiological effectors. Science, N.Y. 199, 146-152.

Hoskins, D.D., Stephens, D.T. \& Hall, M.L. (1974) Cyclic adenosine $3^{\prime}: 5^{\prime}$-monophosphate and protein kinase levels in developing bovine spermatozoa. $J$. Reprod. Fert. 37, 131-133.

Kadohama, N. \& Turkington, R.W. (1974) Changes in acidic chromatin proteins during the hormonedependent development of rat testis and epididymis. J. biol. Chem. 249, 6225-6233.

Kuo, W.N. \& Williams, J.L. (1979) Ontogenetic changes in relative levels of cyclic AMP-dependent and cyclic GMP-dependent protein kinases in prostates, epididymides and testes from guinea-pigs. Experientia 35, 158-159.

Lee, M.Y.W. \& Iverson, R.M. (1976) An adenosine 3',5'monophosphate dependent protein kinase from sea urchin spermatozoa. Biochim. Biophys. Acta 429, 123126.

Lee, P.C., Radloff, D., Schweppe, J.S. \& Jungman, R.A. (1976) Testicular protein kinases: characterization of multiple forms and ontogeny. J. biol. Chem. 251, 914921.

Majumder, G.C. (1981) Enzymic characteristics of an ecto-cyclic AMP-dependent protein kinase in rat epididymal spermatozoa. Biochem. J. 195, 111-117.

Mann, T. \& Lutwak-Mann, C. (1981) Epididymis and epididymal semen. In Male Reproductive Function and Semen, pp. 139-160. Springer-Verlag, Berlin.

Reddi, A.H., Ewing, L.L. \& Williams-Ashman, H.G. (1971) Protein phosphokinase reaction in mammalian testis. Biochem. J. 122, 333-345.

Sharma, R.K. (1982) Cyclic nucleotide control of protein kinases. Prog. Nucl. Acid. Res. Mol. Biol. 27, 233-288.

Walter, U. \& Greengard, P. (1981) Cyclic AMPdependent and cyclic GMP-dependent protein kinases of nervous tissue. Curr. Top. Cell. Reg. 19, 219256

Received 16 November 1982 